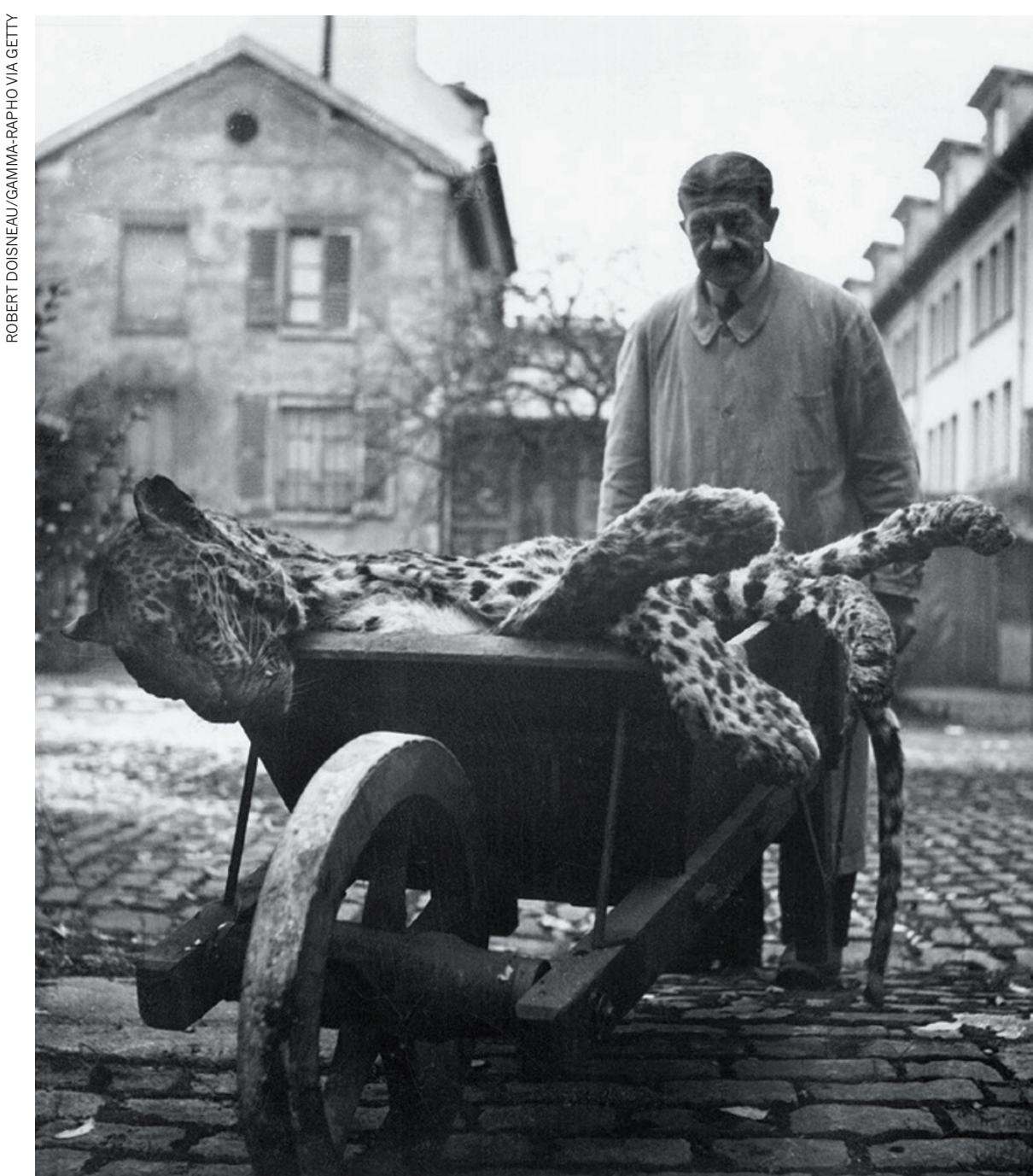

The Funeral Procession of the Jaguar: a technician transports a specimen in 1943.

\title{
PHOTOGRAPHY
}

\section{Sedition in the stores}

\section{Laura Spinney extols Robert Doisneau's haunting images of the Paris natural history museum under occupation.}

I n 1942, French photographer Robert Doisneau (perhaps best known for his image of a couple kissing outside the Hotel de Ville) was commissioned to record life behind the scenes at the various arms of the National Museum of Natural History (MNHN) in Paris. Most of the images have never been published. They are a unique document of the work of a research institute in occupied France during the Second World War. Now, a small
Robert Doisneau: A Photographer at the Museum

French Nationa Museum of Natural History, Paris. Until 18 January 2016.

Maximilien Vox (real name, Samuel Monod), acting on behalf of the Vichy government. Sympathetic to the Germans, this puppet regime wanted to vaunt the vitality of French intellectual life under its beneficent new rulers.

Why did Doisneau agree to such a dubious assignment? Recently returned from the army, he probably just needed the cash. His first baby had only recently been born, and a commission from Vox was not something that a young photographer turned down. Furthermore, lauding France's academic excellence need not have struck him as a betrayal.

What Doisneau found as he toured the museums and gardens was a vibrant research institute - despite, rather than because of, the intrusion of world events. Paul Rivet, director of the MNHN's Museum of Man, was in exile in Colombia. Others had just returned from military service or prisoner-of-war camps including the palaeontologist Camille Arambourg, now remembered for defending Neanderthals against accusations of simian brutishness.

A demobilized botanist, André Guillaumin, was searching for coal to heat the vast greenhouses. A major effort was under way to reorganize the collections, which were just starting to return, having been evacuated in 1939. Publication had been slowed but not stopped by the censors. At the Museum of Man, a resistance cell had been dismantled and its members executed or deported.

Emerging from such tensions, the images take on extra significance. Doisneau wrote later that he was struck by the contrast between the moment of history he inhabited - of which his growling stomach served as a constant reminder - and the geological epochs spanned by the collections. He used that contrast to powerful effect.

Some of the images seem downright insolent, such as that of Paul Budker of the Laboratory of Fish and Colonial Animals gazing into a jar of baby sharks - a Frenchman inspecting imprisoned predators. Others find a wistful wisdom in scenes from the museum's daily life. One such is The Funeral Procession of the Jaguar: the beast is pushed in a wheelbarrow over cobbles to the taxidermy department. Another, showing a white-coated woman with a wizened corpse on her hip and a faraway look in her eyes, Doisneau entitled The Surprising Lightness of a Peruvian Mummy.

Vox had envisaged a collection 
called The Face of Science. Overtaken by events, it never saw the light of day. In November 1942, Allied forces landed in North Africa, prompting the Germans to invade previously unoccupied southern France, rendering the Vichy government impotent. The photos were consigned to the museum library.

In 1990, the museum invited Doisneau back to complete his project. This postscript was a good idea: the contrast between the two sets of photos speaks volumes. Doisneau was in his late seventies and famous. The museum, too, had changed, and Doisneau delighted in discovering its three new subterranean floors of storage. The later images are as closely observed as the earlier ones. But now - as in a picture of a stuffed gorilla in a lift, emerging from or descending into the museum's bowels - the irony is less loaded, and the delight floats free.

Laura Spinney is a writer and science journalist based in Paris.

e-mail:lfspinney@gmail.com

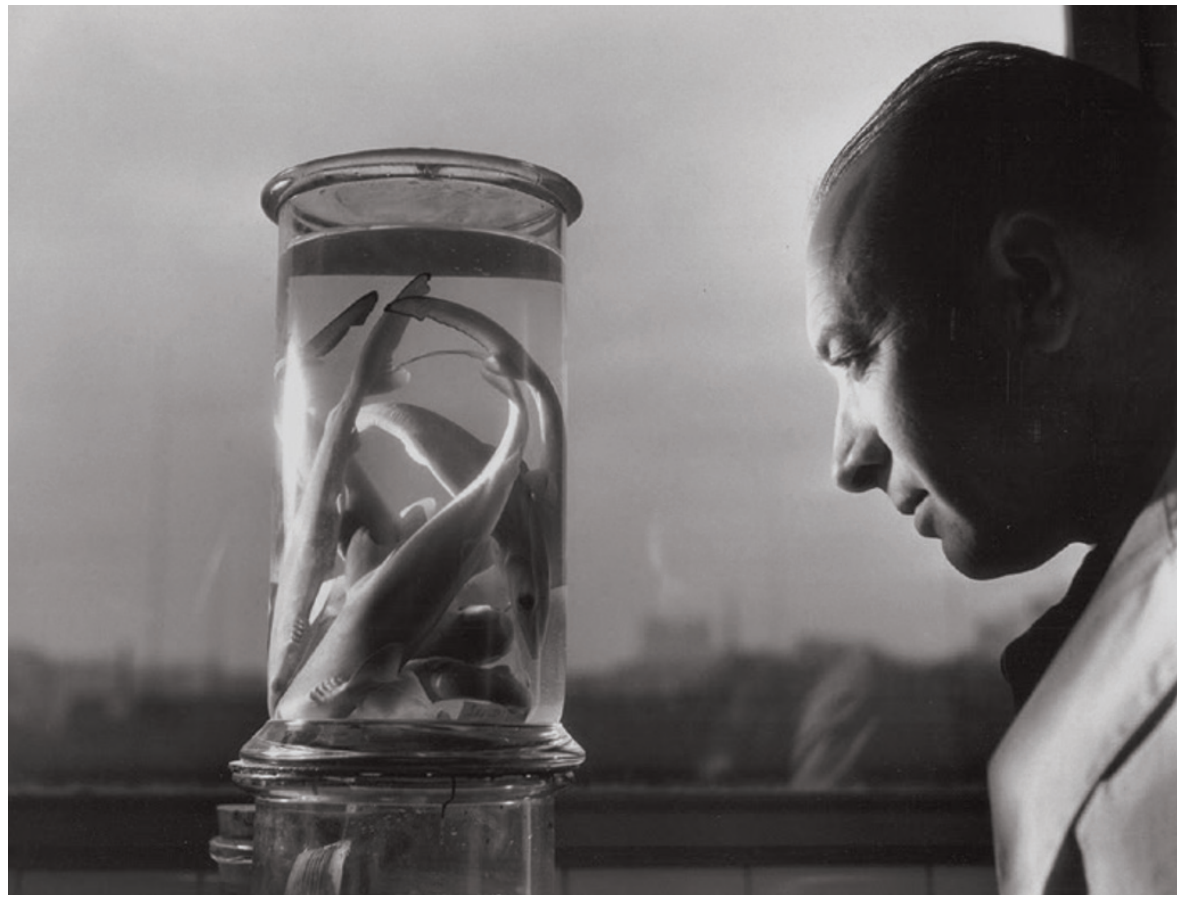

Paul Budker of the Laboratory of Fish and Colonial Animals with a jar of baby sharks in 1943.

\section{Tales of the unexpected}

\section{Stuart Firestein relishes Helga Nowotny's study of uncertainty in science and society.}

$\mathrm{F}$ or scientists, uncertainty is a norm. Experiments begin with uncertainty (why else do them?), and even when they are 'successful', the results contain only a range of certainty and a range of confidence about that certainty. Yet in the world outside the laboratory, uncertainty is perceived as negative - not a data point, but a failing, effectively no better than not knowing.

Social scientist Helga Nowotny, former president of the European Research Council, has written The Cunning of Uncertainty, a tour of the phenomenon and its value to the individual researcher, to the infrastructure of research and to society. Coping with uncertainty, Nowotny declares, must become a collective achievement. Otherwise, the scientific community risks becoming an elite, with all the suspicion and mistrust that that engenders.

As Nowotny shows in numerous examples from the social sciences, historical literature and current media, society's misunderstanding of uncertainty has already led to confusion, distortion and politicization of science (in the debates on tobacco and on climate change, for instance). Billions of dollars of public and private money are poured into research, largely on the false assumption that science provides cold, hard, immutable facts. This attitude is reinforced by an educational system that treats science as an immense 'fact tract' to be memorized (and then largely forgotten), producing a populace that believes science is about answers, rather than questions.

Nowotny deserves high praise for bringing a discussion of the uncertainty around uncertainty into the public arena. She does so with remarkable aplomb given the subject's slipperiness. She challenges scientists to take a leading role in setting straight the distorted views of certainty in science, and then spreading the word to educational and political policymakers.

I was puzzled at first by Nowotny's use of "cunning", a term denoting a worrisome craftiness - cleverness mixed with predatory wiliness. However, Nowotny has nailed

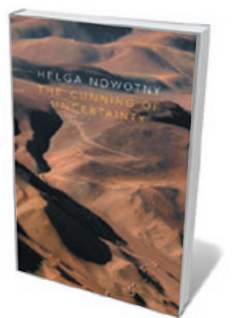

The Cunning of Uncertainty HELGA NOWOTNY Polity: 2015. it: uncertainty has a duality. It is a space that allows creativity, but it is fraught with insecurity. Nowotny herself struggles to disentangle uncertainty from the unexpected, the unpredictable, the dangerous. She sometimes fails, but the exercise is instructive. We take too much for granted, she shows, in defining uncertainty; there are many subtleties and layers to it. From antiquity, people used prognosticators and magicians to look into the future; futurologists are still consulted. Yet people insist on 'spoiler alerts' before sports results are announced, or in film or book reviews; and few want to guess, much less know, the exact moment and circumstances of their too-certain deaths. Definitely cunning.

Nowotny examines this tension through historical examples of how policy is set in areas of uncertainty. These are: reproductive technologies such as in vitro fertilization; stem-cell science; and personalized medicine. With the exception of the last example, these seem like old stories. A discussion of more current and contentious policies, such as genetically modified organisms or nuclear power, might have been more instructive. However, her analyses of big-data programmes (the trumpeted then debunked 